\title{
Interaction of Rhizoctonia solani and Rhizopus stolonifer Causing Root Rot of Sugar Beet
}

\author{
L. E. Hanson, USDA-ARS, Sugar Beet and Bean Research Unit, 494 PSSB, Michigan State University, East Lans- \\ ing 48824-1325
}

\begin{abstract}
Hanson, L. E. 2010. Interaction of Rhizoctonia solani and Rhizopus stolonifer causing root rot of sugar beet. Plant Dis. 94:504-509.

In recent years, growers in Michigan and other sugar beet (Beta vulgaris) production areas of the United States have reported increasing incidence of root rot with little or no crown or foliar symptoms in sugar beet with Rhizoctonia crown and root rot. In addition, Rhizoctonia-resistant beets have been reported with higher levels of disease than expected. In examining beets with Rhizoctonia root rot in Michigan, over 50\% of sampled roots had a second potential root rot pathogen, Rhizopus stolonifer. Growing conditions generally were not conducive to disease production by this pathogen alone, so we investigated the potential for interaction between these two pathogens. In greenhouse tests, four of five sugar beet varieties had more severe root rot symptoms when inoculated with both pathogens than when inoculated with either pathogen alone. This synergism occurred under conditions that were not conducive to disease production by $R$. stolonifer. Host resistance to Rhizoctonia crown and root rot reduced diseases severity, but was insufficient to control the disease when both pathogens were present. This raises concerns about correct disease diagnosis and management practices and indicates that a root rot complex may be important on sugar beet in Michigan.
\end{abstract}

In 2007 and 2008, beets were collected in Michigan commercial sugar beet (Beta vulgaris L.) fields that had severe root rot symptoms. Over the 2 years, 18 fields were sampled from five different counties, with isolations done from three to six beets per field. Two fungal genera, Rhizopus and Fusarium, were isolated from 50 to $60 \%$ of these beets, in addition to Rhizoctonia solani Kühn. While R. solani and Fusarium have been reported as part of a root rot complex in sugar beet (17), and the author had isolated the two pathogens together in samples from Colorado and Wyoming between 2001 and 2006 (unpublished), Rhizopus had not been isolated from field beets in these prior samples. The potential for interaction between Rhizopus and Rhizoctonia is not known.

Corresponding author: Linda E. Hanson E-mail: linda.hanson@ars.usda.gov

Mention of trade names or commercial products in this article is solely for the purpose of providing specific information and does not imply recommendation or endorsement by the U.S. Department of Agriculture.

Accepted for publication 7 January 2010.

doi:10.1094/PDIS-94-5-0504

This article is in the public domain and not copyrightable. It may be freely reprinted with customary crediting of the source. The American Phytopathological Society, 2010.
This research investigates the potential for interaction between Rhizoctonia solani and Rhizopus stolonifer (Ehrenb.) Vuill.

Rhizoctonia crown and root rot (RCRR) has been the most important soilborne fungal disease of sugar beet in the United States for many years $(11,13,36)$ and is increasingly becoming a problem in Europe $(3,5)$. The primary causal agent is $R$. solani anastomosis group (AG) $2-2$ $(36,38)$. The crown rot stage of the disease is the most obvious form, causing sudden and permanent wilting of the leaves, with leaves having dark petioles $(13,16)$. When the root rot stage is present, foliar symptoms may not appear, or be as obvious, until the disease is well advanced. RCRR usually causes a dry, firm, dark rot that affects primarily the root surface with little penetration deep into the root until the disease is far advanced $(13,36)$. Two intraspecific groups (ISG) of $R$. solani can be involved, AG-2-2 IIIB and AG-2-2 IV, with AG-2-2 IIIB usually more virulent (12). We found both ISG in Michigan in recent screening of isolates (unpublished data).

Management of RCRR includes crop rotation $(5,13,16)$, host resistance $(5,16)$, and fungicides $(16,20,21,43)$. However, all three have limitations. Rotation with nonhost crops for at least 3 years is recommended for RCRR management, but $R$. solani AG-2-2 isolates can infect a number of diverse crops $(31,33,38,41)$, and the limited number of nonhost crops compatible with the sugar beet rotation often creates problems with a rotation management strategy. Commercial varieties with resistance are available, but a yield reduction usually is associated with high levels of resistance (3), and most of the beets show a tolerance that can be overcome with high inoculum densities. Fungicides have shown efficacy, but timing of application is critical for disease control $(20,21)$, and the fungicides currently labeled are not systemic.

Rhizopus root rot, caused by $R$. arrhizus or $R$. stolonifer $(13,37)$, has been reported in several growing areas in the United States $(37,42)$ and in Europe $(19,24,37)$. It causes a dark, penetrating root rot that is often soft and spongy (13). The disease most commonly is associated with conditions of excess moisture $(11,13,18,37,39)$ or other stresses such as insect injury $(13,18,24)$ or mechanical root damage (13). Recent reports, however, also associate the disease with drought $(19,24)$. Regulating soil moisture and avoiding beet injury are the primary recommended disease management practices $(17,18,37)$, but the Rhizopus root rot usually is a minor problem and few or no controls are necessary.

$R$. solani is reported as a component in a number of root rot complexes $(2,7,9,25)$ and may be synergistic with several types of pathogens, including nematodes (1), bacteria $(25,40)$, oomycetes $(22)$, and fungi $(9,25)$. The potential for interactions between $R$. solani and other pathogens of beet also have been reported (15, review by 22,40$)$.

This research was conducted to investigate the potential for interactions between $R$. solani and Rhizopus stolonifer in causing root rot of sugar beet and their effects on symptom production and host resistance, a major disease management strategy.

\section{MATERIALS AND METHODS}

Isolates of $R$. solani and Rhizopus stolonifer were obtained from sugar beet plants showing root rot symptoms or from culture collections of fungi from sugar beet. For Rhizopus stolonifer, tissue was cut from the edge of a lesion in the beet cortex, and pieces (approximately $0.5 \mathrm{~cm}^{2} \times 2 \mathrm{~mm}$ deep) were surface-treated for $60 \mathrm{~s}$ in a 
$0.5 \%$ sodium hypochlorite solution and placed on potato dextrose agar (PDA; Becton, Dickinson and Co., Sparks, MD). Plates were incubated at approximately $24^{\circ} \mathrm{C}$ and examined for fungal growth starting 2 days after plating and every 2 days thereafter for up to 14 days. Pure cultures were obtained by spreading spores on water agar (WA) plates, incubating $24 \mathrm{~h}$ at $20^{\circ} \mathrm{C}$, and transferring a single germinated conidium to PDA. Rhizopus isolates were identified to species based on morphology on WA and malt extract agar (MEA; 35) under microscopic examination (35) and growth at $30^{\circ} \mathrm{C}$ but not at $40^{\circ} \mathrm{C}$.

The $R$. solani isolate (R-1) was from the culture collection of E. G. Ruppel (USDAARS, retired, Fort Collins, CO) and originally was collected from diseased sugar beet root. We confirmed its identity as AG2-2 IIIB by paired anastomosis testing with a known tester isolate and by temperature response (38).

Inoculum. Inoculum of $R$. solani was grown for 5 to 7 days on PDA. Plugs (6 $\mathrm{mm}$ diameter) of colonized medium were transferred to sterile unhulled barley grains (one plug per $500 \mathrm{~cm}^{3}$ of barley) that had been soaked in water and autoclaved. Inoculated barley was incubated in closed stainless steel pans at $26^{\circ} \mathrm{C}$ for 21 days. Colonized barley was air-dried and ground with a mill (Quaker City Mill F No 4, Philadelphia, PA). Ground inoculum was stored at $4^{\circ} \mathrm{C}$ until used.

Rhizopus stolonifer isolates were grown for 7 days on PDA at approximately $22^{\circ} \mathrm{C}$ in the dark. Plates were flooded with $15 \mathrm{ml}$ of sterile water, and plate surfaces and fungal hyphae were scraped gently with a sterile disposable cell spreader to release spores. Spore concentration was determined with a hemacytometer, and spore concentrations were adjusted with sterile distilled water. Spore suspensions were used within $3 \mathrm{~h}$ of preparation.

Inoculations. Sugar beets were planted in commercial potting mix (Bacto high porosity professional planting mix, Michigan Peat Co., Houston, TX) in plastic pots (17 $\mathrm{cm}$ deep by $15 \mathrm{~cm}$ diameter). Beets were fertilized with Osmocote 14-14-14 (Scotts, Marysville, $\mathrm{OH}$ ) and a micronutrient mix (MicroMax, Grace-Sierra, Milpitas, CA). Beets were watered when the soil surface was dry to the touch. In the first set of experiments, a RCRR-susceptible commercial cultivar, USH20 (8), and a RCRR-resistant germplasm, FC716 (30), were used to look for interactions between the pathogens. To determine whether the response was variety-specific, three commercial varieties, designated here as 27,28 , and 32, were tested separately. Pots were arranged in a completely randomized design, with four pots (one plant per pot) for each treatment. Insects were controlled by applications of a combination of potassium salts of fatty acids (M-Pede, Dow AgroSciences, Indianapolis, IN) and Beauveria bassiana (Botanigard, Laverlam International Corp., Butte, MT). The greenhouse was maintained at 21 to $25^{\circ} \mathrm{C}$.

Eight weeks after planting, beets were inoculated with $R$. solani by digging a small depression in the potting mix immediately adjacent to the beet crown and placing approximately $0.6 \mathrm{ml}$ of the barley preparation into this depression with a measuring spoon. Potting mix was placed over the barley and plants were watered lightly. For Rhizopus stolonifer inoculations, a $10-\mathrm{ml}$ spore suspension $\left(1 \times 10^{4}\right.$ spores per $\mathrm{ml}$ ) was placed on the beet crown with a sterile pipette. Control plants had sterile ground barley and $10 \mathrm{ml}$ of sterile water applied, respectively. Treatments included control, Rhizopus stolonifer alone (with sterile barley added), Rhizoctonia solani alone (with sterile water applied to the crown), and a combination of both. Plants were maintained as described above. After 4 weeks, beets were removed from the potting mix and roots were washed under running tap water to remove residual potting mix. Beets were examined for root lesions, and the percent surface area showing symptoms was recorded. In addition, each root was rated for disease severity based on a 0 to 7 scale $(27,32)$, where $0=$ no disease, $1=$ a small amount of surface scarring, 2 to $6=$ increasing percentages of the root tissue showing rot, and $7=$ root completely rotted and foliage dead. Each root was rated and an average disease severity rating calculated for each treatment. In addition, each root was cut longitudinally to examine for internal symptoms. Tissue was taken from the edge of lesions (where present) or from internal root tissue where side initials were present when no symptoms were observed. Three roots for each treatment were used from each experiment for isolation attempts, with three or four tissue pieces taken from the edge of lesions per root. Isolation was done as described above for Rhizopus to confirm presence of the pathogen(s). Resulting fungi were compared morphologically to those used in initial inoculations. All experiments were repeated at least once.

Statistical methods. Statistical analyses were performed using SAS (SAS Institute. Cary, NC). The Brown and Forsythe test was used to test for homogeneity of variances. Because homogeneity of variances was not found for the experiments $(P<$ 0.01 ), analyses of variance (ANOVA) were performed for disease ratings for each experiment separately. As all ANOVA tests were significant $(P<0.05)$, mean separations were conducted for each variety using the macro PDMIX800.sas (34) with Tukey adjustments.

\section{RESULTS}

From field samples, rots from which Rhizopus was isolated in addition to Rhizoctonia were generally penetrating, brown lesions. On the surface, lesions were dark brown to almost black, as is typical for RCRR (36). Internally, most lesions were light to dark brown, which can occur with either root rot $(36,37)$. One sample had an acetic acid-like odor as has been described for severe Rhizopus root $\operatorname{rot}(37)$.

Rhizopus isolates were identified as Rhizopus stolonifer by the presence of coenocytic hyphae with sporangiophores ( 2 to $4 \mathrm{~mm}$ long) formed on stolons opposite complex, well-developed rhizoids. Isolates grew at $30^{\circ} \mathrm{C}$ but showed no growth at $40^{\circ} \mathrm{C}$.

In the first greenhouse experiment, using USH20 and FC716, no disease symptoms were observed on plants of either variety with the control treatments (Fig. 1A). No clear rot symptoms were observed on plants treated with the Rhizopus stolonifer spore suspension alone (Fig. 1B), although some surface scarring was observed on the crowns. Lesions typical for RCRR were observed on the susceptible variety when treated with $R$. solani alone (Fig. 1C). More extensive root discoloration was observed on beets exposed to the combination of the two pathogens (Fig. 1D), for both the susceptible and the resistant material. Little in the way of foliar damage was observed for any treatment. In the first time through the experiment, small spots and surface scarring were observed on the resistant germplasm (FC716) exposed to $R$. solani alone and visible root rot when exposed to the combined pathogens. In the second time through the experiment, no symptoms were seen on the resistant germplasm when exposed to $R$. solani alone, but rot was present when both $R$. solani and Rhizopus stolonifer were combined. Analysis is shown for the first time through the experiment in which symptoms were observed on the resistant germplasm (Table 1). Results were similar for the second time through the experiment. When root ratings were compared (Table 1), disease severity ratings were increased significantly $(P<0.05)$ for the combined pathogens compared to the $R$. solani treatment alone. A significant increase in disease severity for the combined pathogen treatment was observed for all tests $(P<0.05)$. The susceptible variety had a higher disease severity rating than the resistant in the combined pathogen treatment (Table 1), but both showed a higher disease rating than with either pathogen alone.

Similar results were observed for the commercial cultivars, with no rot symptoms, just some surface scarring, on the control plants or those treated with Rhizopus stolonifer alone. All three varieties had significantly higher ratings following treatment with Rhizoctonia solani compared with the control (Table 2). Significantly greater disease severity was observed on two of the three commercial 
sugar beet varieties examined following combined exposure to the two fungi. The exception was variety 28 , which had no significant difference in disease severity between $R$. solani alone or in combination with $R$. stolonifer (Table 2). This variety had the highest disease rating with $R$. solani alone of any of the beet varieties or germplasm tested.

When infected roots were cut open to reveal interior symptoms, control plants and those treated with only Rhizopus showed little or no internal discoloration as seen with susceptible variety USH20 (Fig. 2A). Susceptible plants treated with $R$. solani had shallow, dark lesions that penetrated less than $1 \mathrm{~cm}$ into the interior of the root (Fig. 2B), while several plants treated with the combined pathogens had extensive internal discoloration (Fig. 2C), which usually was somewhat soft, and often lighter colored than that caused by $R$. solani alone.

All plants showing symptoms of root rot yielded $R$. solani from the tissue at the edge of lesions. No Rhizoctonia or Rhizopus was cultured from noninoculated plants. No Rhizoctonia was isolated from plants inoculated with Rhizopus alone. Rhizopus stolonifer was isolated only from plants inoculated with this organism, but was not isolated from all inoculated plants. $R$. stolonifer was isolated from two $R$. stolonifer-inoculated plants in the commercial variety experiments that showed no root rot symptoms but had surface scar- ring. Isolates were obtained from internal root tissue where side root initials were present. R. stolonifer also was isolated from at least one lesion from roots of each variety from the combined inoculation plants in all of the experiments. It was isolated from lesions of the deeper, more penetrating rot and softer rot areas, but it was not isolated from all lesions sampled,

Table 1. Response of a Rhizoctonia crown and root rot-susceptible sugar beet commercial cultivar (USH20) and a Rhizoctonia crown and root rot-resistant germplasm (FC716) to inoculation with Rhizoctonia solani AG-2-2 IIIB with and without Rhizopus stolonifer ${ }^{\mathrm{W}}$

\begin{tabular}{llccl}
\hline & \multicolumn{4}{c}{ Fungal treatment $^{\mathbf{x}}$} \\
\cline { 2 - 5 } Sugar beet type $^{\mathrm{y}}$ & Control & Rhizopus & Rhizoctonia & Combined fungi $^{\mathrm{n}}$ \\
\cline { 2 - 5 } USH20 & $0 \mathrm{c}(0 \%)^{\mathrm{z}}$ & $0.5 \mathrm{c}(<5 \%)$ & $3.5 \mathrm{~b}(20-30 \%)$ & $5.5 \mathrm{a}(60-80 \%)$ \\
FC716 & $0 \mathrm{~b}(0 \%)$ & $0.5 \mathrm{~b}(<5 \%)$ & $1 \mathrm{~b}(\leq 5 \%)$ & $3 \mathrm{a}(15-25 \%)$ \\
\hline
\end{tabular}

${ }^{\text {w }}$ Plants were grown for 4 weeks after inoculation and rated for root rot severity. Results shown are from the first of two times this experiment was conducted.

Treatments included a spore suspension of $1 \times 10^{4}$ spores per $\mathrm{ml}$ of Rhizopus, $0.6 \mathrm{ml}$ of a dried ground barley inoculum of $R$. solani, or a mix of the two. Control plants were treated with sterile ground barley and sterile water. Each value is the average of four plants.

y Sugar beets tested were commercial variety USH20 (Rhizoctonia susceptible) or USDA released Rhizoctonia root rot-resistant germplasm FC716.

Average disease severity ratings and (range of percent surface area affected). Numbers for each variety followed by the same letter are not significantly different by Tukeys $(P=0.05)$.
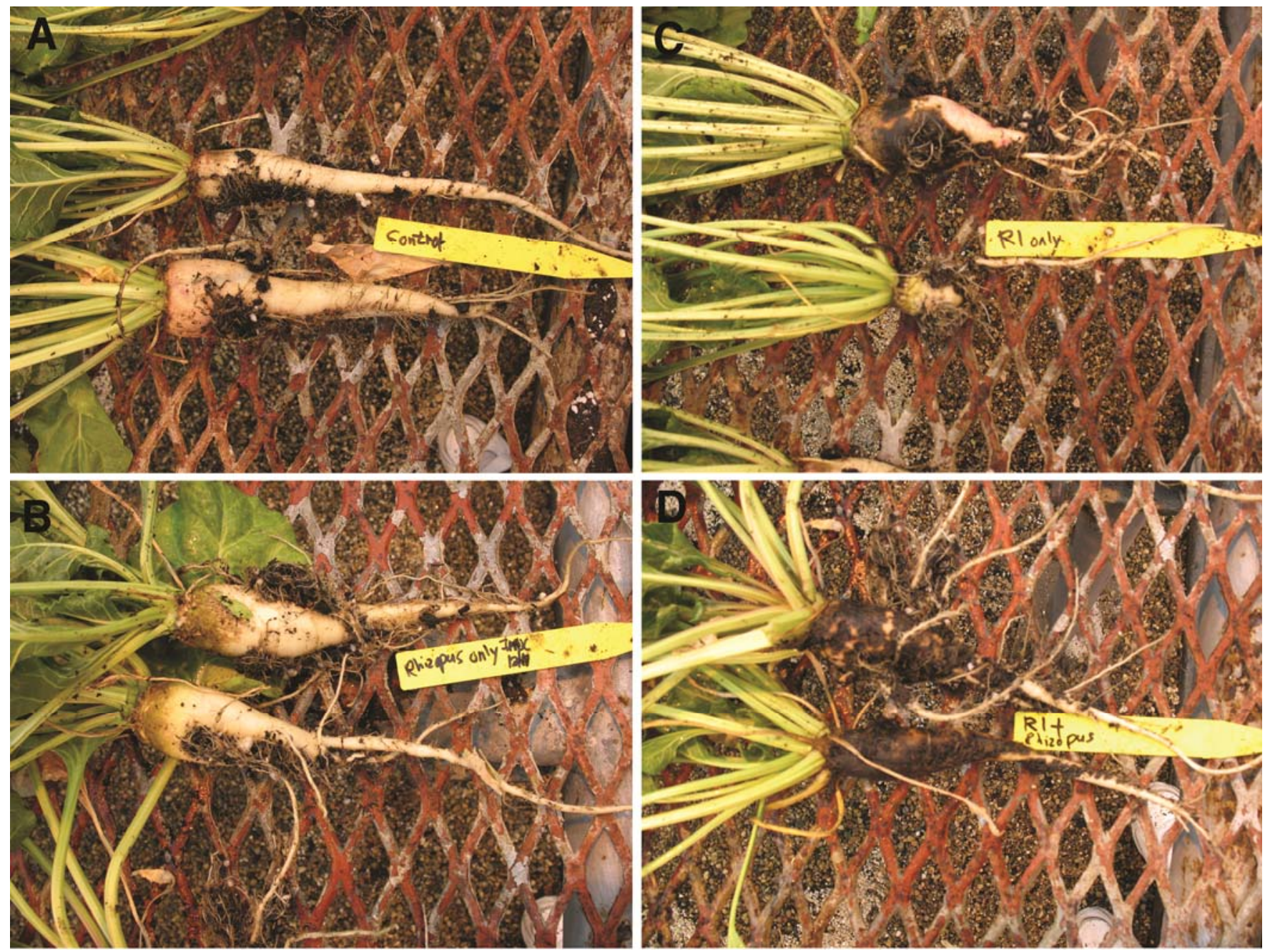

Fig. 1. Response of sugar beets to inoculation with fungi. Plants shown are sugar beet variety USH20, a Rhizoctonia-susceptible variety. Plants were harvested 4 weeks after inoculation. A, Control plants treated with sterile ground barley and sterile water. B, Plants treated with an aqueous spore suspension of Rhizopus sp. and sterile ground barley. C, Plants treated with a barley inoculum of Rhizoctonia solani AG-2-2 and sterile water. D, Plants treated with a combination of a spore suspension of Rhizopus and a barley inoculum of Rhizoctonia solani. 
particularly the dark, surface-rot areas. $R$. solani was isolated from all lesions sampled in the combined pathogen treatments.

\section{DISCUSSION}

More severe disease was observed when three of four sugar beet varieties and one germplasm were exposed to a combination of Rhizoctonia solani AG-2-2 IIIB and
Rhizopus stolonifer than when plants were exposed to either pathogen alone. This increased disease severity was greater than that obtained by adding the severities of the two pathogens together, and thus appeared to be synergistic. The increased disease severities occurred under conditions not reported as conducive to disease production by Rhizopus sp. Roots were not exposed to excess moisture, drought, or insect damage. Despite this, in the combined inoculations, beets showed disease symptoms that appeared to be a combination of the two pathogens, as lesions penetrated well into the beet and often were soft, as would be expected with Rhizopus infection, rather than being the firm texture usually associated with RCRR $(36,37)$; but
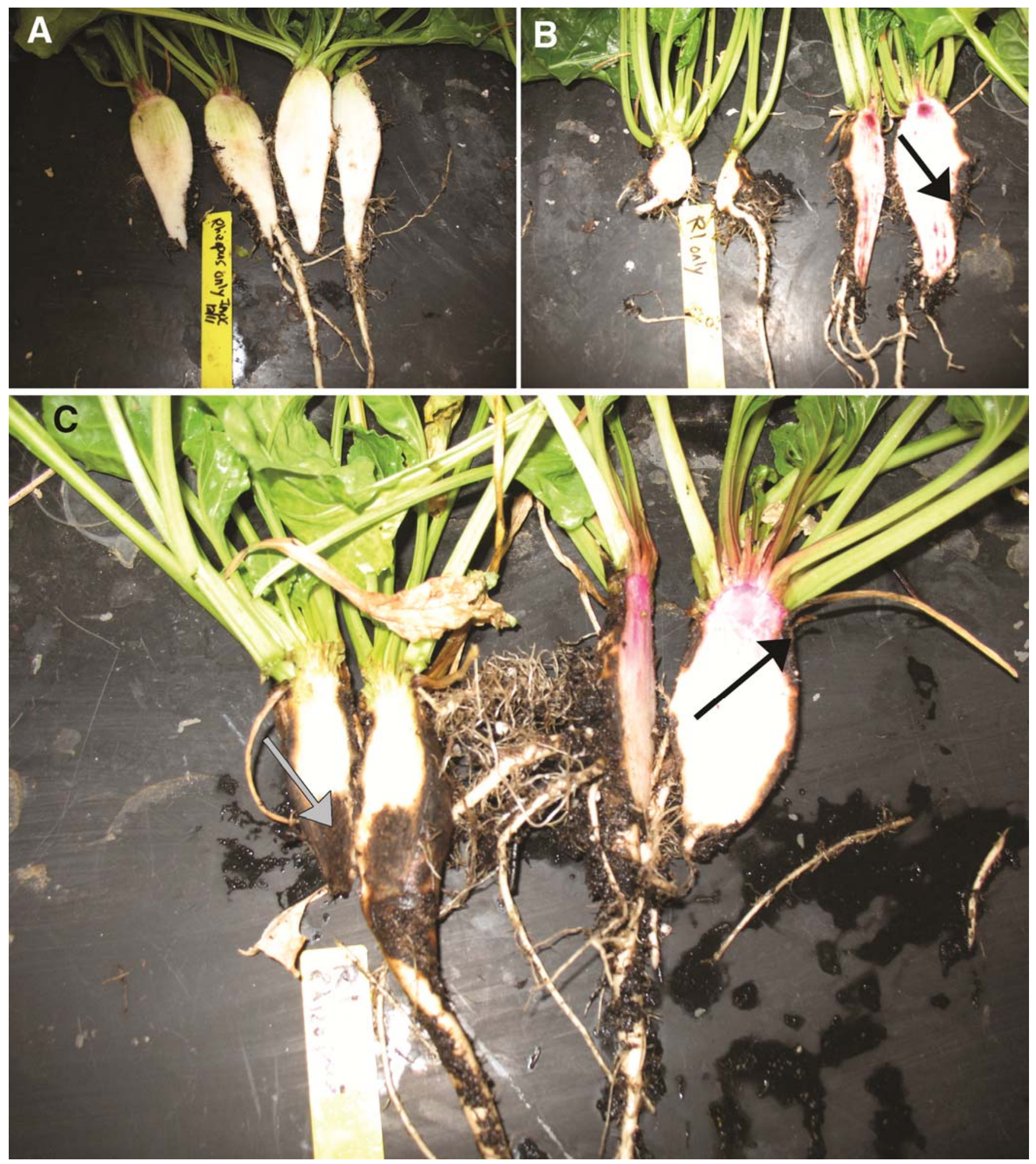

Fig. 2. Internal symptoms on a Rhizoctonia crown and root rot-susceptible sugar beet variety USH20 following inoculation with A, Rhizopus sp. alone, B, Rhizoctonia solani AG-2-2 IIIB alone, or C, a combination of both. Black arrows indicate dark, firm, shallow lesions typical of Rhizoctonia crown and root rot. Gray arrows indicate penetrating lesions. 
the surface or parts of the lesions were firm and darker (Fig. 2C), as is typical for RRCR. In some cases, portions of the lesions were light brown, appearing more similar to symptoms of Rhizopus root rot (37) than the very dark brown to black lesions normally produced by RCRR $(13,16,36)$, although both can produce light brown internal lesions $(36,37)$.

The one variety that did not show this response may have been too susceptible to RCRR to show increased disease severity with the combined pathogens, as it had a higher disease severity rating in the presence of $R$. solani alone than did the other varieties. It might be that differences would be seen under lower Rhizoctoniainoculum pressure with this variety. Alternatively, this variety might have some resistance to Rhizopus. No resistance to Rhizopus has been reported in beets and no significant difference was found among these three varieties when inoculated with Rhizopus as a postharvest rot (unpublished data). It is possible, however, that different responses may occur while the beet is growing compared to postharvest conditions.

Conditions in the fields where the Rhizopus stolonifer isolates were collected were not those generally reported for Rhizopus root rot. Soils where most of the samples were collected were not waterlogged. For example, in 2007, two samples that yielded $R$. stolonifer in July were from an area where the soil moisture had a maximum of $0.421 \mathrm{~cm}^{3} / \mathrm{cm}^{3}$ and an average of $0.186 \mathrm{~cm}^{3} / \mathrm{cm}^{3}$ for the 30 days prior to samples being taken, according to data from the Michigan Automated Weather Network (http://www.agweather.geo.msu. edu/mawn/). The maximum soil temperature was $27^{\circ} \mathrm{C}$, and the minimum was $17^{\circ} \mathrm{C}$ for the same time period.

One concern raised by these results relates to screening for RCRR resistance in sugar beet. Resistance does occur (14, review in 29) and is in commercial use for disease management. These results (Table 1) indicate that when both pathogens were present, as well as when only $R$. solani was present, the Rhizoctonia-resistant variety had a lower disease severity than the Rhizoctonia-susceptible variety. The increased disease severity observed with the combined pathogens in the resistant germplasm FC716 was similar to that of the susceptible variety USH20 when exposed to $R$. solani alone (Table 1 ). If a resistant variety were planted in a field with both pathogens without a susceptible variety for comparison, there would be a potential perceived loss of resistance, as disease levels could be similar to those observed in a susceptible variety exposed to $R$. solani. If a susceptible variety were present, the relative disease levels could indicate that the resistant variety still has less disease than a susceptible. Growers in some areas have expressed concern about poor performance of host resistance. It is not known if a mixed infection could be involved in some of these situations.

While disease severity increased with the combined pathogens, resistance to RCRR showed some promise in controlling the disease even when both pathogens were present. The germplasm FC716, with a high level of resistance to RCRR, had lower disease severity in the presence of the combined pathogens than did a susceptible variety (USH20). However, disease severity in this germplasm exposed to the combined pathogens for 4 weeks was above the level considered harvestable $(27,28)$, while it would have been at levels acceptable for harvest if exposed to $R$. solani alone (Table 1). Thus, if the two pathogens are interacting in a field, other control measures than host resistance may be necessary.

The production of symptoms typical of Rhizopus from only plants treated with a combination of the two pathogens indicates that, under these growing conditions, which are not those typically reported to lead to Rhizopus root rot (37), Rhizopus stolonifer was not able to cause disease by itself. It apparently required the activity of Rhizoctonia solani to infect the plants. This does not appear to be simply by creat-

Table 2. Response of three commercial sugar beet cultivars, 27, 28, and 32, to inoculation with Rhizoctonia solani AG-2-2 IIIB with and without Rhizopus stolonifer ${ }^{\mathrm{V}}$

\begin{tabular}{lccl}
\hline & \multicolumn{3}{c}{ Average disease severity rating $^{\mathbf{w}}$} \\
\cline { 2 - 4 } Fungal treatment $^{\mathbf{x}}$ & $\mathbf{2 7}$ & $\mathbf{2 8}$ & $\mathbf{3 2}$ \\
\hline Control & $0.5 \mathrm{c}^{\mathbf{y}}$ & $0.0 \mathrm{~b}$ & $0.0 \mathrm{c}$ \\
Rhizopus & $0.5 \mathrm{c}$ & $0.3 \mathrm{~b}$ & $0.5 \mathrm{bc}$ \\
Rhizoctonia & $2.8 \mathrm{~b}$ & $4.3 \mathrm{a}$ & $2.3 \mathrm{~b}$ \\
Rhizopus + Rhizoc. & $5.3 \mathrm{a}$ & $5.8 \mathrm{a}$ & $5.0 \mathrm{a}$ \\
\hline
\end{tabular}

${ }^{\mathrm{v}}$ Plants were inoculated with a spore suspension of Rhizopus or sterile water and a ground barley inoculum of $R$. solani or sterile ground barley. Control plants were treated with sterile ground barley and sterile water. Plants were grown for 4 weeks after inoculation, harvested, and rated for root rot severity. Results shown are from the first of two times this experiment was conducted.

${ }^{\text {w }}$ Disease severity rating on a 0 to 7 scale where $0=$ no disease and $7=$ root completely rotted. All numbers are the average of four plants.

${ }^{x}$ Fungal treatments included a spore suspension of $1 \times 10^{4}$ spores per $\mathrm{ml}$ of Rhizopus, $0.6 \mathrm{ml}$ of a dried ground barley inoculum of $R$. solani or a mix of the two. Control plants were treated with sterile ground barley and sterile water.

y Sugar beet commercial varieties are designated 27, 28, and 32.

${ }^{\mathrm{z}}$ Numbers for each variety followed by the same letter are not significantly different by Tukeys $(P=0.05)$. ing a wound, since a subset of plants of USH20 that were wounded by making a hole with a \#4 cork borer at the soil surface prior to inoculation did not show any Rhizopus root rot symptoms (data not shown). The isolation of Rhizopus only from some of the tissues in the plants treated with the combined pathogens may indicate limited spread of the pathogen in the host, poor competition with $R$. solani in the host or on the isolation media, or a preferential colonization of certain tissues. This could be of concern for identifying the presence of this pathogen in the field. Also, while the crown was inoculated with Rhizopus stolonifer, most of the isolations of $R$. stolonifer occurred from root tissue below the soil surface, particularly in the root tissue at or below the area where the lateral roots were visible.

It may be that the isolates of R. stolonifer used in this study have low virulence. None of the isolates in this study had been collected as the sole pathogen in beet. All had been isolated from beets from which $R$. solani also had been isolated. This is not unexpected, as Rhizopus species are generally classified as weak parasites that cause disease when beets are "not developing normally" (37). The ability of these isolates to cause disease under conditions conducive to Rhizopus root rot, such excessive soil moisture, 14 to $16^{\circ} \mathrm{C}$ temperature, and injuries to the beet is being investigated.

As noted in Figure 1, plants showed very few foliar symptoms for any of the treatments tested, in contrast to what has been reported for RCRR, where foliar symptoms of chlorosis of the foliage and black necrosis of the petioles are commonly reported (36). A lack of foliar damage (Fig. 1D) in the field can make determination of whether a field should be harvested difficult, and might result in more severely rotted beets being taken for processing than is desirable.

As well as having the potential to cause root rot in the field, Rhizopus spp. also can be postharvest pathogens of sugar beet $(4,23$, cited in 24). The presence of this pathogen in beets in the field might contribute to inoculum for postharvest rot. The contribution of field infection with both of these root rot pathogens to postharvest deterioration needs to be determined.

This study shows an interaction between the two soilborne fungi, Rhizoctonia solani AG-2-2 IIIB and Rhizopus stolonifer, that increases root rot severity in infected beets. Root rot complexes involving $R$. solani and other soilborne fungi have been reported on several crops $(6,9,10,25,26)$ and may be an important factor for beet. Further investigations on the potential for interactions between the other major form of the RCRR pathogen of sugar beet, $R$. solani AG-2-2 IV, and Rhizopus stolonifer and into the conditions under which this disease interaction occurs is warranted. 


\section{ACKNOWLEDGMENTS}

I thank T. D. Goodwill for valuable technical assistance and S. Poindexter and Michigan Sugar for providing beet samples.

\section{LITERATURE CITED}

1. Ali, S. S., and Venugopal, M. N. 1992. Interaction between Meloidogyne incognita and Rhizoctonia solani in damping-off and rhizome rot disease of cardamom seedlings. Nematol. Mediterr. 20:65-66.

2. Botha, A., Denman, S, Lamprecht, S. C., Mazzola, M., and Crous, P. W. 2003. Characterization and pathogenicity of Rhizoctonia isolates associated with black root rot of strawberries in the Western Cape Province, South Africa. Australas. Plant Pathol. 32:195201.

3. Buddemeyer, J., and Märländer, B. 2005. Genotypic reaction of sugar beet to Rhizoctonia solani root and crown rot - Susceptibility, yield and quality at different levels of infestation. J. Plant Dis. Prot. 112:105-117.

4. Bugbee, W. M. 1986. Storage rot of sugar beet. Pages 37-39 in: Compendium of Beet Diseases and Insects. E. D. Whitney and J. E. Duffus, eds. American Phytopathological Society, St. Paul, MN.

5. Buhre, C., Kluth, C., Bürcky, K., Märländer, B., and Varrelmann, M. 2009. Integrated control of root and crown rot in sugar beet: Combined effects of cultivar, crop rotation, and soil tillage. Plant Dis. 93:155-161.

6. Burke, D. W., and Hall, R., revised by Harveson, R. M., and Yuen, G. 2005. Fusarium root rot. Pages 13-15 in: Compendium of Bean Diseases, 2nd ed. H. F. Schwartz, J. R. Steadman, R. Hall, and R. L. Forster, eds. American Phytopathological Society, St. Paul, MN.

7. Chang, K. F., Mirza, M., and Hwang, S. F. 1993. Etiology of a root rot disease complex of Alstromeria in Alberta, Canada. J. Phytopathol. 137:207-213

8. Coe, G. E., and Hogaboam, G. J. 1971. Registration of USH20 sugar beet. Crop Sci. 1:942.

9. Datnoff, L. E., and Sinclair, J. B. 1988. Interaction of Fusarium oxysporum and Rhizoctonia solani in causing root rot of soybean. Phytopathology 78:771-777.

10. de Jensen, C. E., Kurle, J. E., and Percich, J. A. 2004. Integrated management of edaphic and biotic factors limiting yield of irrigated soybean and dry bean in Minnesota. Field Crop Res. 86:211-224.

11. Edson, H. A. 1915. Seedling diseases of sugar beets and their relation to root-rot and crownrot. J. Agric. Res. 4:135-168.

12. Engelkes, C. A., and Windels, C. E. 1996. Susceptibility of sugar beet and beans to Rhizoctonia solani AG-2-2 IIIB and AG-2-2 IV. Plant Dis. 80:1413-1417.

13. Franc, G. D., Harveson, R. M., Kerr, E. D., and Jacobsen, B. J. 2001. Disease management. Pages 131-160 in: Sugarbeet Production Guide. R. G. Wilson, J. A. Smith, and S. D.
Miller, eds. University of Nebraska, Lincoln, NE.

14. Gaskill, J. O. 1968. Breeding for Rhizoctonia resistance in sugarbeet. J. Am. Soc. Sugar Beet Technol. 15:107-119.

15. Harveson, R. M. 2007. Aphanomyces root rot of sugar beet. Univ. Nebr. Ext. Publ. G1407.

16. Harveson, R. M. 2008. Rhizoctonia root and crown rot of sugar beet. Univ. Nebr. Ext. Publ. G1841.

17. Jacobsen, B. J. 2006. Root rot diseases of sugar beet. Proc. Nat. Sci. Matica Srpska Novi Sad. 110:9-19.

18. Kaffka, S., Lewellen, R. T., Frate, C. A., and Turini, T. A. 2005. Sugarbeet Rhizopus Root Rot. UC Pest Management Guidelines: Sugarbeet. UC ANR Publ. 3469.

19. Karadimos, D. A., and Karaoglanidis, G. S. 2006. Survey of root rot diseases of sugar beet in central Greece. Proc. Nat. Sci. Matica Srpska Novi Sad. 110:129-131.

20. Kiewnick, S., Jacobsen, B. J., BraunKiewnick, A., Eckhoff, J. L. A., and Bergman, J. W. 2001. Integrated control of Rhizoctonia crown and root rot of sugar beet with fungicides and antagonistic bacteria. Plant Dis. 85:718-722.

21. Kirk, W. W., Wharton, P. S., Schafer, R. L., Tumbalam, P., Poindexter, S., Guza, C., Fogg, R., Schlatter, T., Stewart, J., Hubbell, L., and Ruppal, D. 2008. Optimizing fungicide timing for the control of Rhizoctonia crown and root rot of sugar beet using soil temperature and plant growth stages. Plant Dis. 92:1091-1098.

22. Martin, H. L. 2003. Management of soilborne diseases of beetroot in Australia: A review. Aust. J. Exp. Agric. 43:1281-1292.

23. Miles, W. G., Shaker, F. M., Nielson, A. K., and Ames, R. R. 1977. A laboratory study on the ability of fungicides to control beet rotting fungi. J. ASSBT 19:288-293.

24. Moliszewska E. B., and Wisniewski, W. 2006. Infestation of sugar beet fields by Rhizopus arrhizus in atypical weather conditions in the summer of 2006. Phytopathol. Pol. 41:75-78.

25. Nyvall, R. F. 1999. Diseases of alfalfa. Pages 3-43 in: Field Crop Diseases, 3rd ed. Iowa State University, Ames.

26. O'Brien, R. G., O'Hare, P. J., and Glass, R. J. 1991. Cultural practices in the control of bean root rot. Aust. J. Exp. Agric. 31:551-555.

27. Panella, L., and Hanson, L. E. 2001. Publicly released sugar beet germplasm evaluated for resistance to Rhizoctonia root-rot, 2000. Biol. Cultural Tests Control Plant Dis. 16:F18. DOI: 10.1094/BC16. The American Phytopathological Society, St. Paul, MN

28. Panella, L., Lewellen, R. T., and Hanson, L. E. 2008. Breeding for multiple disease resistance in sugarbeet: Registration of FC220 and FC221. J. Plant Registrations 2:146-155.

29. Panella, L., and Ruppel, E. G. 1996. Availability of germplasm for resistance against Rhizoctonia spp. Pages 515-527 in: Rhizoctonia spe- cies: Taxonomy, Molecular Biology, Ecology, Pathology, and Disease Control. B. Sneh, S. Jabaji-Hare, S. Neate, and G. Dijat eds. Kluwer Academic Publishers, Dordrecht, Netherlands.

30. Panella, L. W., Ruppel, E. G., and Hecker, R. J. 1994. Registration of four multigerm sugarbeet germplasms resistant to Rhizoctonia root rot: FC716, FC717, FC718 and FC719. Crop Sci. 34:291-292.

31. Ruppel, E. G. 1985. Susceptibility of rotation crops to a root rot isolate of Rhizoctonia solani from sugar beet and survival of the pathogen in crop residues. Plant Dis. 69:871-873.

32. Ruppel, E. G., Schneider, C. L., Hecker, R. J., and Hogaboam, G. J. 1979. Creating epiphytotics of Rhizoctonia root rot and evaluating for resistance to Rhizoctonia solani in sugarbeet field plots. Plant Dis. Rep. 63:518522.

33. Rush, C. M., Carling, D. E., Harveson, R. M., and Mathieson, J. T. 1994. Prevalence and pathogenicity of anastomosis groups of Rhizoctonia solani from wheat and sugar beet in Texas. Plant Dis. 78:349-352.

34. Saxton, A. M. 1998. A macro for converting mean separation output to letter groupings in Proc Mixed. Pages 1243-1246 in: Proc. 23rd SAS Users Group Intl. SAS Institute, Cary, NC.

35. Schipper, M. A. A. 1984. A revision of the genus Rhizopus I. The Rhizopus stolonifergroup and Rhizopus oryzae. Studies Mycol. 25:1-19.

36. Schneider, C. L., and Whitney, E. D. 1986 Rhizoctonia root and crown rot. Page 21 in Compendium of Beet Diseases and Insects. E. D. Whitney and J. E. Duffus, eds. American Phytopathological Society, St. Paul, MN.

37. Schneider, C. L., and Whitney, E. D. 1986. Rhizopus root rot. Pages 21-22 in: Compendium of Beet Diseases and Insects. E. D. Whitney and J. E. Duffus, eds. American Phytopathological Society, St. Paul, MN.

38. Sneh, B., Burpee, L., and Ogoshi, A. 1991. Identification of Rhizoctonia Species. American Phytopathological Society, St. Paul, MN.

39. Stanghellini, M. E., and Kronland, V. C. 1977. Root rot of mature sugar beets by Rhizopus arrhizus. Plant Dis. Rep. 61:255-256.

40. Strausbaugh, C. A., and Gillen, A. M. 2008. Bacteria and yeast associated with sugar beet root rot at harvest in the Intermountain West. Plant Dis. 92:357-363.

41. Sumner, D. R., and Bell, D. K. 1982. Root diseases induced in corn by Rhizoctonia solani and Rhizoctonia zeae. Phytopathology 72:8691.

42. Vincelli, P. C., and Gurne, J. C. 1989. Root rot of sugar beet in Wyoming caused by Rhizopus arrhizus. Plant Dis. 73:518.

43. Windels, C. E., and Brantner, J. R. 2005 Early-season application of azoxystrobin to sugarbeet for control of Rhizoctonia solani AG 4 and AG 2-2. J. Sugar Beet Res. 42:1-17. 